\title{
Diet, reproduction and population structure of the introduced Amazonian fish Cichla piquiti (Perciformes: Cichlidae) in the Cachoeira Dourada reservoir (Paranaíba River, central Brazil)
}

\author{
Tatiane Ferraz Luiz ${ }^{1 *}$, Marcela Roquetti Velludo ${ }^{1}$, Alberto Carvalho Peret ${ }^{1}$, Jorge Luiz Rodrigues \\ Filho $^{1} \&$ André Moldenhauer Peret ${ }^{1}$ \\ 1. Population Dynamics Laboratory, Department of Hydrobiology, Federal University of São Carlos (UFSCar) \\ Washington Luís Highway (SP-310), km 235. São Carlos, SP, Brazil. Zip Code 13565-905; tatianeferrazluiz@ hotmail. \\ com,marcelavelludo@gmail.com,peret@ufscar.br,jorlrf@hotmail.com, andreperet@yahoo.com \\ * Correspondence.
}

Received 10-VI-2010. Corrected 02-XI-2010. Accepted 14-XII-2010.

\begin{abstract}
The Blue Peacock Bass (Cichla piquiti), native to the Tocantins-Araguaia river basin of the Amazon system, was introduced into the basin of the Paranaíba River, Paraná River system. Cachoeira Dourada reservoir is one of a series of dams on the Paranaíba River in central Brazil, where this fish has become established. A study of its feeding spectrum, combined with information about its reproductive characteristics and population structure, would enable the current state of this species in the reservoir to be assessed and might provide useful data for the management of other species native to this habitat. This study showed that the peacock bass has no predators or natural competitors in the reservoir and that reproduces continuously, with high reproductive rates, and has a smaller median length at first maturity (L50) than other species of Cichla. Its successful establishment in habitats strongly affected by human activity should cause changes in the whole structure of the local fish communities. Nonetheless, in this reservoir, there appears to be some sharing of the functions of this species with native carnivorous fish, a situation that may be sustained by the presence of a wide variety of foraging fish. Rev. Biol. Trop. 59 (2): 727-741. Epub 2011 June 01.
\end{abstract}

Key words: Cichla piquiti, invasive species, population structure, diet, fish reproduction.

The introduction of non-native species into new habitats is the second biggest cause of species extinctions, the first being disappearance of the habitats themselves (Simberloff 2003). Apart from causing local extinctions, the introduction of exotic or allochthonous species also has a wider impact on food chains, the balance among various community populations and functional relations in the ecosystems (Rocha et al. 2005). The potential for a successful invasion is determined by the properties of the invading species, such as its tolerance of widely different environmental conditions, dispersion and fast colonization of the habitat, aggressiveness, competitiveness and high reproductive rate (Grime 1979), by its value to the fishing industry (Moyle et al.1986), and by the characteristics of the local species, namely their competitiveness and capacity to resist, and of the community being invaded (Sakai et al. 2001).

The impact of invasion by a fish is likely to be negative if the species introduced is carnivorous or piscivorous (Moyle \& Cech 1996). Being more aggressive than other species, carnivores are relatively easy to introduce and such invasions are recognized as one of the most powerful biological means of transforming native communities. When there are neither predators nor pathogens in the new community capable of attacking the invader, its population may grow very fast, owing to the greater resources available to it, which 
strengthen its competitiveness (Blossey \& Notzold 1995, Tilman 1999). The problem has worsened by the fact that a fish introduced into an ecosystem cannot be selectively eliminated (Kaufman 1992, Simberloff 2003).

The blue peacock bass (locally known as tucunaré), Cichla piquiti Kullander \& Ferreira, 2006 , occurs naturally in the drainage basin of the Tocantins and Araguaia Rivers (Kullander \& Ferreira 2006). In these floodplain ecosystems, the trophic relations of fish communities are affected by a number of factors, such as the properties of the surrounding ecosystem, the feeding flexibility of the species and the effects of seasonal variation on the availability of food resources. The seasonal changes in the water level provoke variations in limnological characteristics, in the availability of food and the migration of species. Thus, the trophic interactions in such systems are very dynamic and complex (Benedito-Cecilio \& Araújo-Lima 2002).

The blue peacock fish is now widely established in the reservoirs of the Paraná River basin in the Brazilian states of Minas Gerais and São Paulo, including the basin of the Paranaíba (Kullander \& Ferreira 2006). Several dams in this system lead to changes in its physical, chemical and biological attributes, greatly modifying the biotic interactions and resulting in a simplified ecosystem (Agostinho \& Zallewski 1995). Such changes lead to a decrease in recruitment, replacement of the fauna by opportunist species (Agostinho et al. 1994) and modification of the food chain, often resulting in the disappearance of small species (Zaret \& Paine 1973, Godinho et al. 1994). In this context, a study of the feeding spectrum of Cichla piquiti in the Cachoeira Dourada reservoir on the Paranaíba River, along with the data on its reproductive features and population structure, would contribute towards an assessment of the current state of this cichlid in the habitat and also provide information that could be used in the management of other exotic invaders.

\section{MATERIAL AND METHODS}

The Cachoeira Dourada reservoir

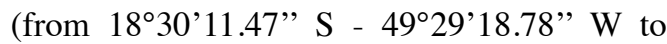
$18^{\circ} 34^{\prime} 5.27^{\prime \prime} \mathrm{S}-49^{\circ} 19^{\prime} 52.07^{\prime \prime} \mathrm{W}$ ) is situated on the boundary between the states of Minas Gerais and Goiás in the central region of Brazil (Fig. 1). It has a volume of $524000000 \mathrm{~m}^{3}$ and was created in 1966 by the construction of one of a complex of dams along the Paranaíba River (tributary of the Paraná), whose drainage basin extends over $3111 \mathrm{~km}^{2}$ (Cabral et al. 2005).

The original vegetation around the reservoir, composed of semi-deciduous tropical forest and cerrado (shrubby savannah), with transition zones between the two, has been cleared and replaced by cattle pasture and crop fields. The flow of water from the catchment area into the Paranaíba follows a well-defined seasonal pattern (Cabral et al. 2005). The oneyear study reported herein covered the period of high water, from October to March, and drought, from April to September.

The physical and chemical attributes of the water were measured with a Yellow Spring multiprobe. This revealed high levels of dissolved oxygen in the reservoir, varying from 5.28 to $9.16 \mathrm{mg} / \mathrm{L}$. The water temperature was rather high throughout the year of sampling, between 22.6 and $27.4^{\circ} \mathrm{C}$, while the electrical conductivity was low, from 0.02 to $0.04 \mu \mathrm{S} / \mathrm{s}$, and the $\mathrm{pH}$ varied from 5.80 to 7.35 . The trophic state of the reservoir varied from oligotrophic, in the dry period, to mesotrophic, when the reservoir was full, according to the Kratzer and Brezonik index (Kratzer \& Brezonik 1981).

The blue peacock bass or blue peacock fish were collected monthly, from January 2007 to January 2008, at three sites covering the whole length of the reservoir. Two batteries of ten gill nets were extended at each site during the sampling, with range of meshes in each battery of 1.5 to $10.0 \mathrm{~cm}$ between adjacent knots. The nets remained under the surface for $24 \mathrm{~h}$ and were inspected at approximately $12 \mathrm{~h}$ intervals. The fish were congealed and taken to the laboratory. 


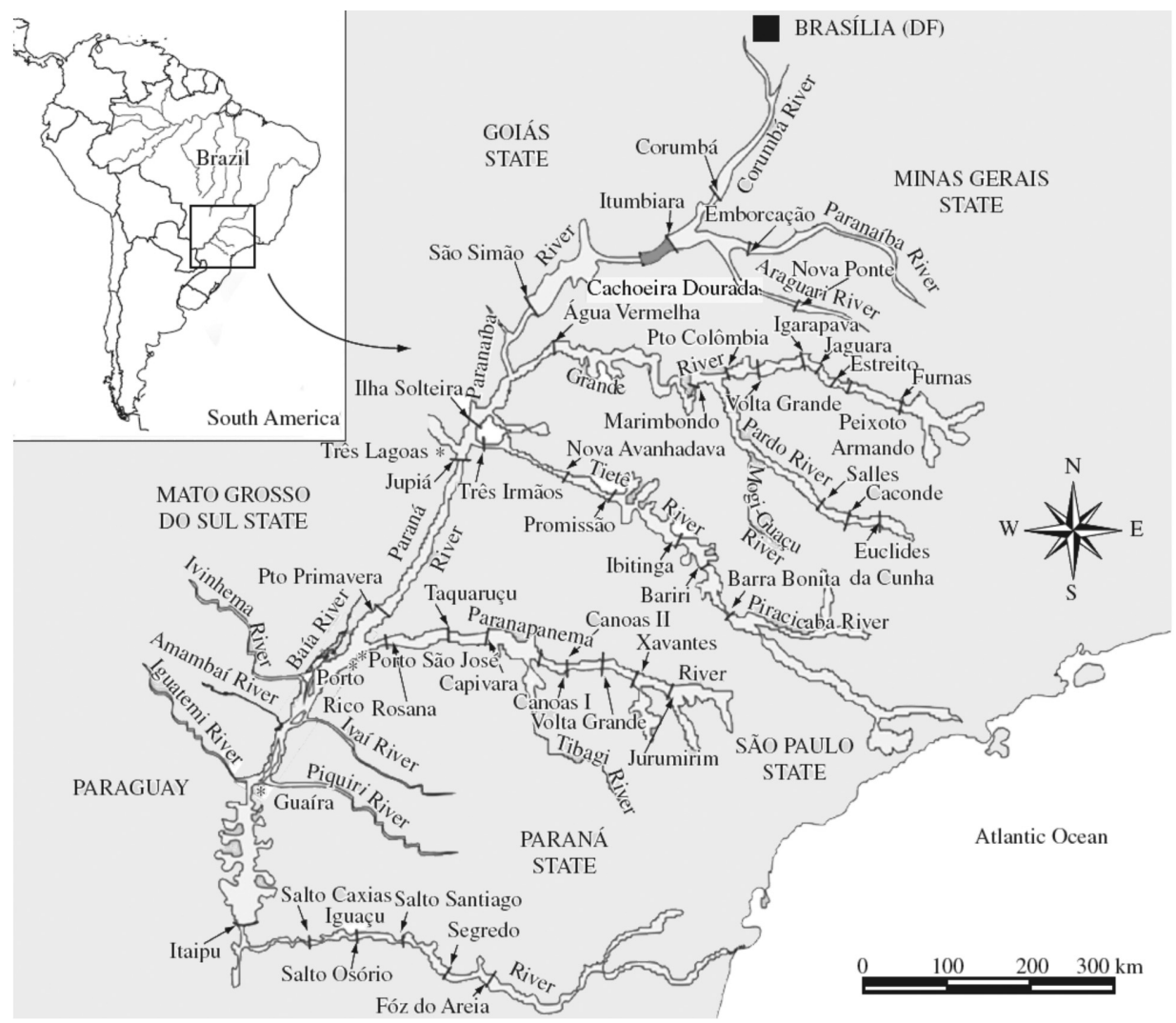

Fig. 1. Cachoeira Dourada reservoir on the Paranaíba River, between Minas Gerais and Goiás States, central Brazil, where this study was conducted (Agostinho et al. 2008).

In the laboratory, the standard and total lengths of fish were measured $( \pm 1 \mathrm{~mm})$ and weighed $( \pm 0.01 \mathrm{~g})$, the gonads were removed and weighed $( \pm 0.01 \mathrm{~g})$. The size distribution of the population was analyzed in terms of size classes: class 1 included specimens of length 12.6 to $15.5 \mathrm{~cm}$, class 2 fish from 15.6 to $18.7 \mathrm{~cm}$, class 3 from 18.8 to $21.9 \mathrm{~cm}$, class 4 from 22.0 to $25.1 \mathrm{~cm}$, class 5 from 25.2 to $28.3 \mathrm{~cm}$, class 6 from 28.4 to $31.5 \mathrm{~cm}$ and class 7 from 31.6 to $34.7 \mathrm{~cm}$. The relationship between weight and length, as suggested by Le Cren (1951), was analyzed for the two sexes as separate groups, and the gradients (b) of the linearized weight-length curves, describing the growth patterns followed by individual fish, were compared by the Student $t$ test $(\mathrm{p}=0.05)$, with n-1 degrees of freedom (Zar 1999). The relative condition factor $(\mathrm{Kr}=\mathrm{Lt} / \mathrm{Wte})$ was calculated for all specimens and their average monthly compared with the central value of 1.0 by the Student $t$-test (two-tail $\mathrm{p}=0.05, \mathrm{n}-1$ ). In order to check representativeness of the average we calculated their standard errors (Le Cren 1951). The water transparency was estimated by means of a Secchi disk, to determine whether it influenced $\mathrm{Kr}$. The stage of maturity of individual fish was determined by macroscopic inspection of the color, transparency and vascularization of the gonads. Thus, female fish were assigned to four distinct stages as follows: A) Immature, B) Maturing, C) Spawning and D) Post-spawning (Vazzoler 1996). Differences in male and female numbers in 
samples of the whole population and for each size class were detected by the chi-squared $\left(\chi^{2}\right)$ test with Yates' correction (Zar 1999). The median length at first maturity (L50) was based on the frequency distribution (of females and/ or males) of the length classes, being defined as the length of the class in which $50 \%$ of the fish have developing gonads, as described by Santos (1978). The female gonadosomatic index (GSI) was calculated, to indicate the functional stage of the ovaries (Vazzoler 1996), and used to produce the maturation curve from which the periods (dry or wet) of intensive reproductive activity were defined.

To study the variation in feeding among the fish, their stomachs were removed, weighed and classified by their degree of fullness, from empty, medium and completely full (Vazzoler 1996). The stomach weight was plotted against total body weight, for each state of fullness. After weighing and classifying, the stomachs were fixed in $4 \%$ formaldehyde.

The fixed stomach contents were examined under the stereo-microscope and the items were identified to the lowest possible taxonomic level to calculate the percentage of occurrence $\left(\mathrm{F}_{\mathrm{i}}\right)$ of each type of item from total (Hyslop 1980). The total volume of item $i$ was also calculated from the volume $\left(\mathrm{V}_{\mathrm{i}}\right)$ of water displaced by item $i$ in a measuring cylinder and the importance of this item in the diet of $C$. piquiti was assessed from the feeding index IAi (Kawakami \& Vazzoler 1980):

$$
I A_{i}=\frac{F_{i} \cdot V_{i}}{\sum_{i=1}^{n}\left(F_{i} \cdot V_{i}\right)}
$$

where: $\mathrm{IA}_{\mathrm{i}}$ is the feeding index of food item $i$ $(i=1,2, \mathrm{n}) ; \mathrm{F}_{i}$ its frequency of occurrence in the $\operatorname{diet}(\%)$ and $\mathrm{V}_{i}$ its percent volume in the diet.

\section{RESULTS}

The transparency of the water (Secchi depth) and the condition factor of the blue peacock fish specimens were higher in the dry period. The low values of the errors of the mean (SE) indicated high representativeness of the parameter in relation to your samples (Fig. 2). In all, 141 Cichla piquiti were collected, with a total biomass of $23.50 \mathrm{~kg} ; 68 \%$ were male, $12 \%$ female and $20 \%$ juvenile. The specimens of each sex showed an exponential relation between weight and length (Fig. 3), characterizing the growth as positive allometric (exponential coefficient, $b>3.0$ ). The weight-length curve was linearized by using logarithmic axes (inset, Fig. 3) and coefficient $b$, the slope of this line, was found to be slightly greater for the females than for the males. However, Student's $t$ test (108 degrees of freedom) showed no significant difference between males and females $(\mathrm{p}>0.05)$. $\mathrm{P}$ values are presented in Table 1 . The linear plots had high coefficients of determination $\left(\mathrm{r}^{2}\right)$, indicating a good fit between the model equation and data (Fig. 3).

The fish of each sex were grouped in 7 length classes. The first one, with the shortest fish, was the most numerous and the numbers of specimens per class decreased steadily with rising length. Specimens of indeterminate sex were found only in the first four classes, while females were present in all classes up to the sixth and males in all the size classes. The population of $C$. piquiti caught in the nets

TABLE 1

Student $t$ test $\mathrm{p}$ values

$\begin{array}{ccc}\text { Month } & \text { Two tailed p value } & \neq 1.0 ? \\ \text { Jan-07 } & 0.1326 & \mathrm{~ns} \\ \text { Feb-07 } & 0.121 & \mathrm{~ns} \\ \text { Mar-07 } & 0.219 & \mathrm{~ns} \\ \text { Apr-07 } & 0.2891 & \mathrm{~ns} \\ \text { May-07 } & & \mathrm{ns} \\ \text { Jun-07 } & 0.1961 & \mathrm{~ns} \\ \text { Jul-07 } & 0.5041 & \mathrm{~ns} \\ \text { Aug-07 } & 0.4468 & \mathrm{~ns} \\ \text { Oct-07 } & 0.2342 & \mathrm{~ns} \\ \text { Nov-07 } & 0.0444 & * \\ \text { Jan-07 } & 0.0095 & * *\end{array}$

Not statistically (ns) significant $(\mathrm{p} \geq 0.05) ; *$ statistically significant $(\mathrm{p}<0.05)$; $* *$ statistical significance $(\mathrm{p}<0.01)$. 


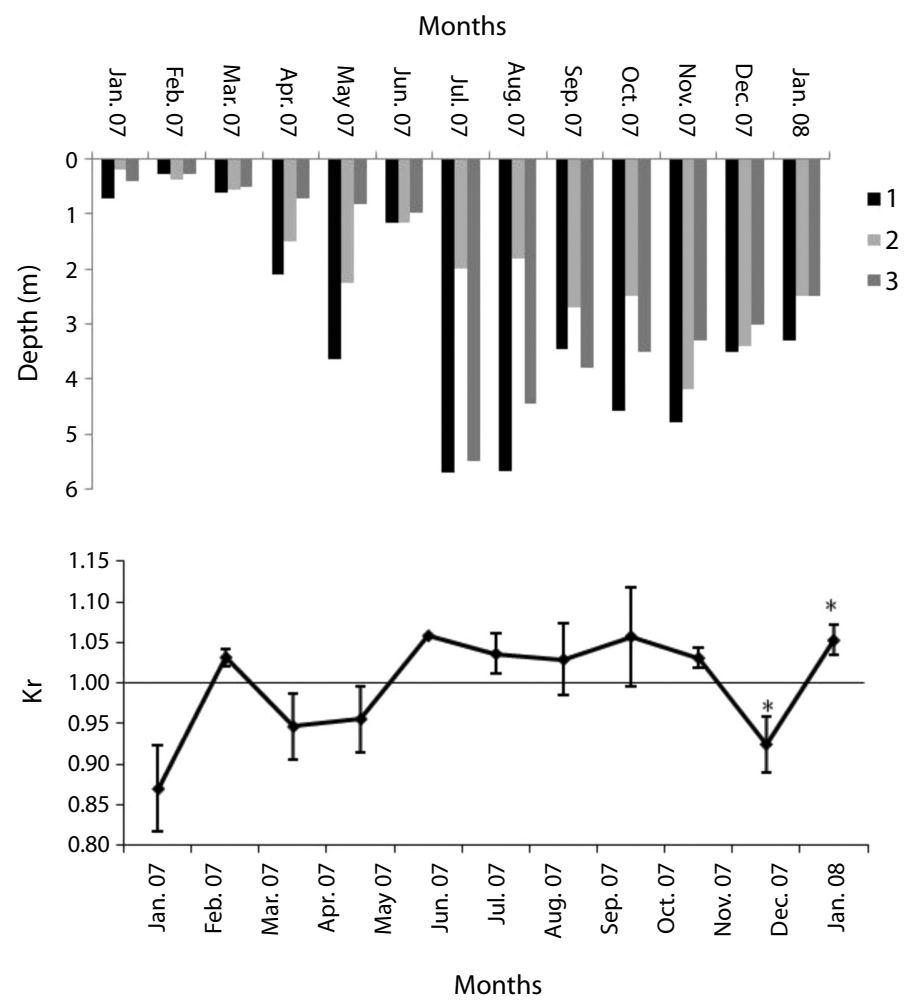

Fig. 2. Monthly water transparency at sites 1,2 and 3 (top), relative condition factor $(\mathrm{Kr})$ and average error (*) of $C$. piquiti in the Cachoeira Dourada reservoir (Paranaíba River basin, central Brazil), from January 2007 to January 2008.

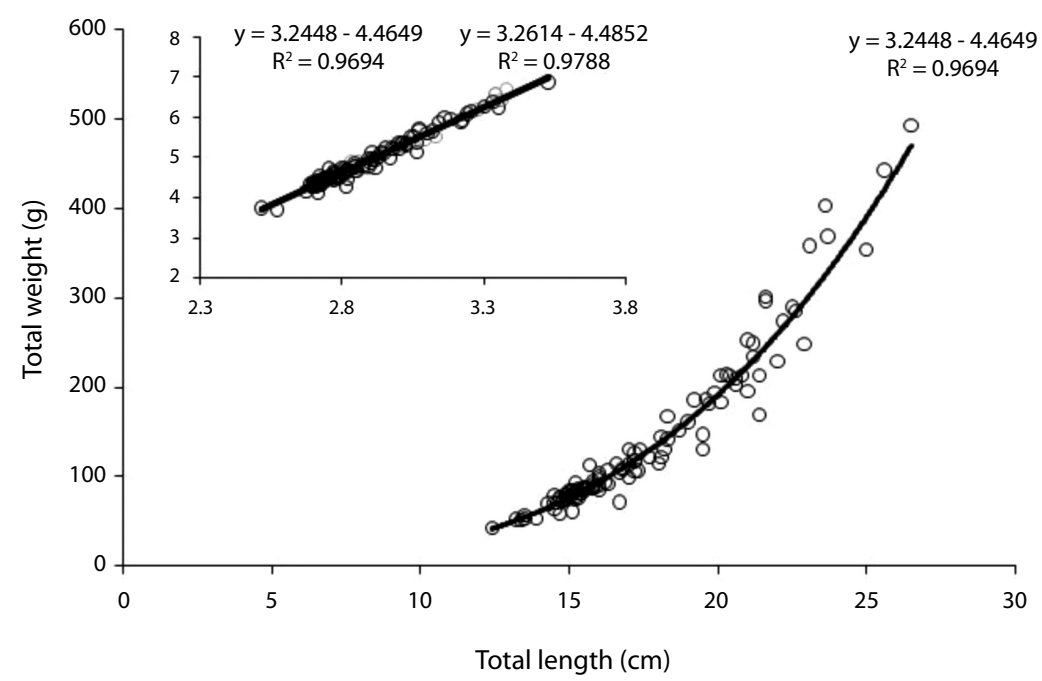

Fig. 3. Length-weight relationship in C. piquiti collected from the Cachoeira Dourada reservoir (Paranaíba River basin, central Brazil) between January 2007 and January 2008. Inset: data in logarithmic axes, with linear equations for male (left) and female (right) fish. 
consisted mainly of males, which exceeded the number of females with the proportion of 5.5:1. By applying the $\chi^{2}$ test to the numbers of male, female and indeterminate fish in each size class, it was found that every class showed significant differences in its composition (Fig. 4). The values of L50 for male and female $C$. piquiti were both $22.5 \mathrm{~cm}$ and those of $\mathrm{L} 100$ were 26.4 and $28.4 \mathrm{~cm}$, respectively (Fig. 5). The GSI of the females was higher in the dry period, when more of the females were in the more advanced reproductive stages (Fig. 6).

Among the 82 analyzed stomachs, 25 of those from the fish caught during the rainy seasons of 2007 and 2008 contained no food items. The types and frequency of occurrence of items found in the stomachs of these fish are listed in Table 2. These items were allocated to four groups: fish, insects, crustaceans and plants. Fish constituted the majority of the food in the blue peacock fish stomachs, revealing the predominantly piscivorous diet of this fish at all stages of its growth (Fig. 7). Fragments of plants, insects and crustaceans played a less important part in the feeding habits of
C. piquiti. The diversity of food items in the stomach was higher in the first four length classes and insects were found only in the first three (Fig. 7). Owing to the advanced stage of digestion, most of the fish found in the stomachs could not be identified $(82.26 \%)$. The following species were identified: Satanoperca papaterra (Heckel 1840), Metynnis maculatus (Lacepède, 1803), Bryconamericus sp., Astyanax sp., Hoplias malabaricus (Bloch 1974), Hoplias lacerdae (Ribeiro 1908), Pinirampus pirinampu (Spix \& Agassiz, 1829), Pimelodella sp. and Serrassalmus sp. Some cannibalism was observed, mainly in the form of juvenile blue peacock fish in the stomach contents. Fish belonging to the families Characidae, Cichlidae, Pimelodidae and Symbranchidae, all of which are typical of lentic habitats, were identified among the food items. The values of the feeding indices for many different items consumed by $C$. piquiti in the dry and wet seasons are shown in Fig. 8. In Fig. 9, the linear plots of the relation between the stomach weight and body weight, for empty, medium full and completely full stomachs, are shown.

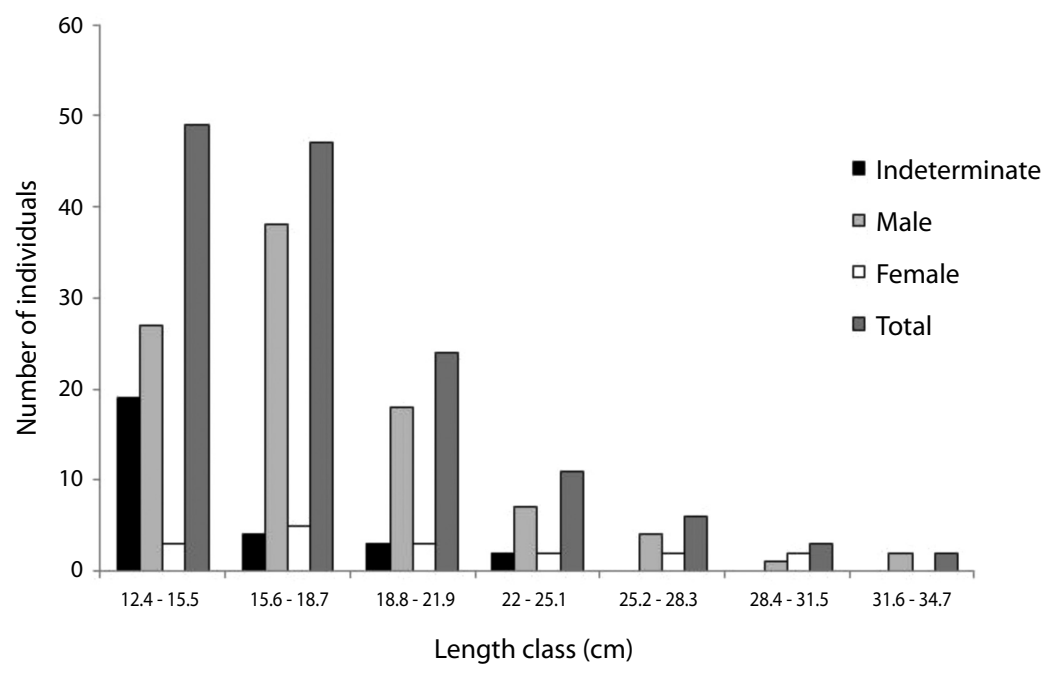

Fig. 4. Size frequency distribution of $C$. piquiti fish collected in the Cachoeira Dourada reservoir (Paranaíba River basin, central Brazil) between January 2007 and January 2008. 


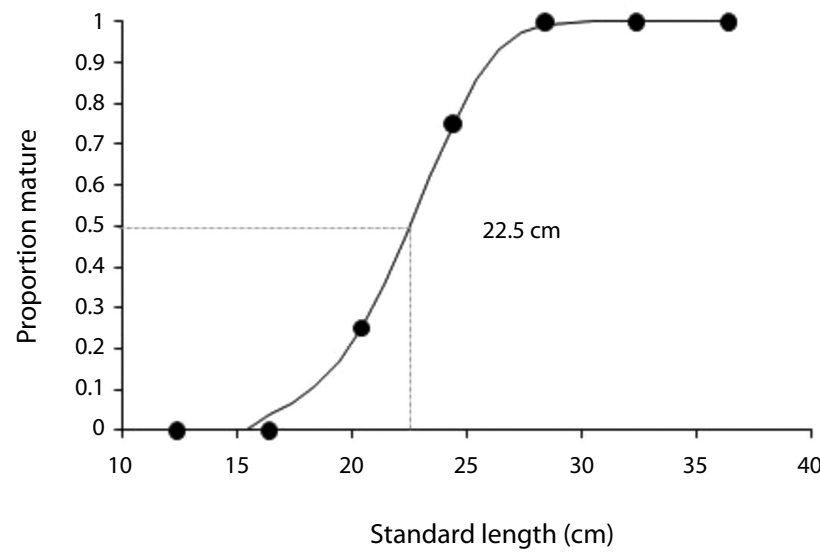

Females

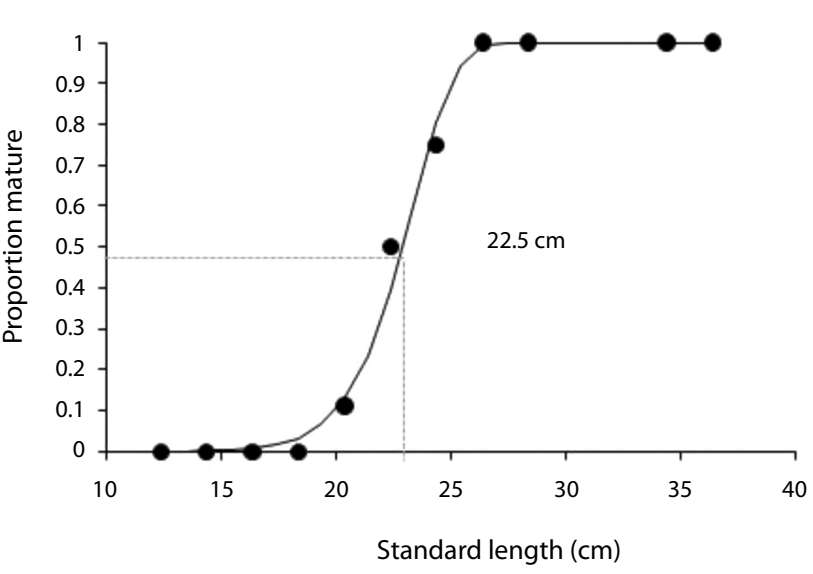

Males

Fig. 5. Proportion of mature females and males for each size class against their median standard length of blue peacock specimens caught in the Cachoeira Dourada reservoir (Paranaíba River basin, Brazil) between January 2007 and January 2008. Estimation of L50 shown in grey lines.

\section{DISCUSSION}

The feeding and hence the fattening of fish in a given habitat are strongly influenced by the environmental conditions along the whole watercourse regulating the availability of food items (Gomiero \& Braga 2005). The transparency of the water was a determining factor, as blue peacock fish are diurnal predators that need clear water to see and catch their prey. Agostinho et al. (2002) report that the still water typical of some reservoirs becomes very transparent, facilitating greatly the predator activity of diurnal fish such as $C$. piquiti.
The relative condition factor $(\mathrm{Kr})$ observed in the blue peacock fish specimens was close to 1.0 , being slightly higher in the dry season. In this period, the higher quality and transparency of the water contributed to raising the efficiency of the fish in catching their prey; this was also the season of fattening for reproduction and higher values of GSI. The decrease of $\mathrm{Kr}$ in the rainy period coincided with the end of the reproductive season of this species and a time of lower feeding activity, during which a higher proportion of stomachs were found to be empty. 


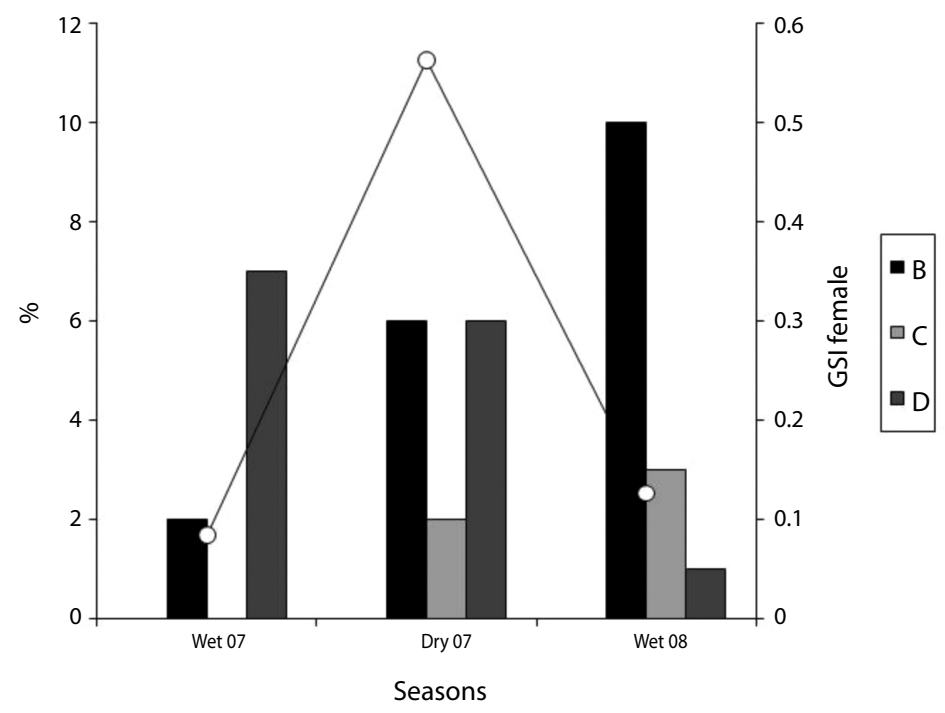

Fig. 6. Frequency percentages of gonad maturity stages (B, C and D) and mean GSI (-o-) among female C.piquiti caught in the Cachoeira Dourada reservoir (Paranaíba River basin, Brazil), during the wet and dry seasons from January 2007 to January 2008.

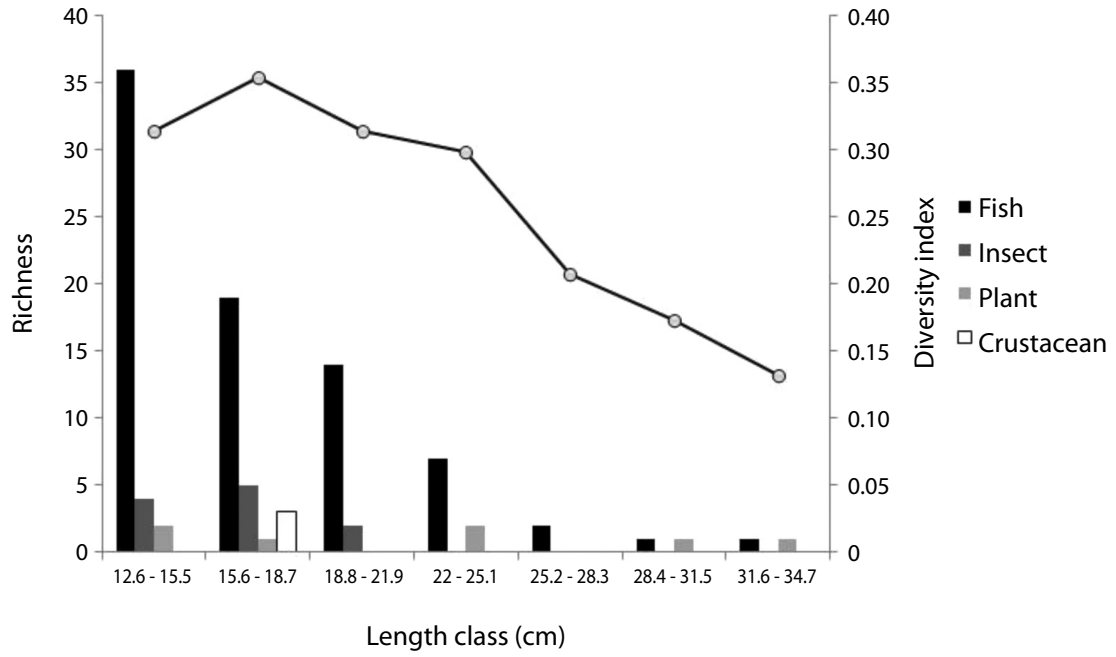

Fig. 7. Overall richness (bars) and diversity indices of the four groups (line) of food items found in stomachs of $C$. piquiti, collected in the Cachoeira Dourada reservoir (Paranaíba River basin, Brazil) between January 2007 and January 2008. 
TABLE 2

Frequency of food items occurrence (F\%) found in stomachs of $C$. piquiti collected from the Cachoeira Dourada reservoir (Paranaíba River basin, Brazil) between January 2007 and January 2008 (n.i. means not identified)

\begin{tabular}{|c|c|c|c|c|}
\hline Groups & Group subcategory & Group sub-subcategory & Species & $\mathrm{F} \%$ \\
\hline \multirow[t]{18}{*}{ Fish } & Fish n.i. & & & 41.13 \\
\hline & Cichlidae & Cichlidae n.i. & & 7.26 \\
\hline & & & S. papaterra & 2.42 \\
\hline & & & C.piquiti & 2.42 \\
\hline & & Scale & & 0.8 \\
\hline & Characidae & Characidae n.i. & & 0.8 \\
\hline & & & M. maculatus & 1.61 \\
\hline & & & Bryconamericus sp. & 2.42 \\
\hline & & & Astyanax sp. & 0.8 \\
\hline & Erythrinidae & & H. malabaricus & 5.64 \\
\hline & & & H. lacerdae & 0.8 \\
\hline & & Scale & & 0.8 \\
\hline & Pimelodidae & Pimelodidae n.i. & & 2.42 \\
\hline & & & P. pirinampu & 1.61 \\
\hline & Synbranchidae & Synbranchidae n.i. & & 1.61 \\
\hline & Heptapteridae & & Pimelodella sp. & 0.8 \\
\hline & Serrassalminae & & Serrassalmus sp. & 7.26 \\
\hline & Modified fin & Spine & & 1.61 \\
\hline \multirow[t]{5}{*}{ Insects } & Insects n.i. & & & 1.61 \\
\hline & Diptera & Chironomidae n.i. & & 3.22 \\
\hline & Ephemeroptera & & & 4.84 \\
\hline & Odonata & & & 0.81 \\
\hline & Trichoptera & & & 0.81 \\
\hline \multirow[t]{2}{*}{ Crustaceans } & Macrobrachium & Post-larvae & & 1.62 \\
\hline & & Adult & & 0.81 \\
\hline \multirow[t]{2}{*}{ Plant } & Plant & Aquatic & & 1.61 \\
\hline & & Terrestrial & & 2.42 \\
\hline
\end{tabular}

The sex ratio showed a clear predominance of male blue peacock fish in all the size classes. In species that exhibit biparental care, such a difference may be expected for this ratio (Gomiero et al. 2009). According to Jepsen et al. (1997), more males tend to be caught during the reproductive period, owing to their aggressive territorial defense and protection of their offspring from any kind of invader. Females guard the eggs and larvae while the males patrol the territory and repel all possible predators (Barlow 1974). Natural mortality rates, differential growth and methods of collection can be further causes of such differences between the sexes (Vazzoler 1996). In the reservoir under study, the maximum length of males was greater than that of females. This can be explained partly in terms of the expenditure of energy on sexual development. Gurgel (2004) points out that the development of the testes is related more to the size of the male fish than to the annual reproductive cycle, whereas in the females, the amount of energy spent on egg formation handicaps their general growth, resulting in smaller asymptotic lengths. LoweMcConnell (1969), Chellapa et al. (2003) and 


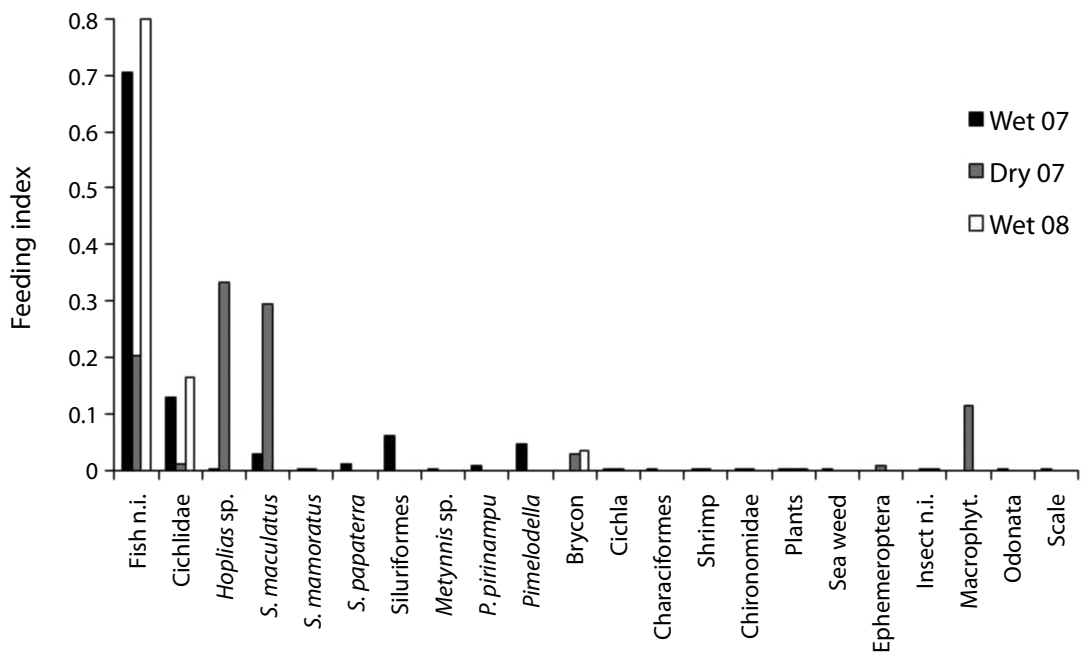

Food items

Fig. 8. Proportion of different food items consumed by C. piquiti collected from the Cachoeira Dourada reservoir (Paranaíba River basin, central Brazil), during the rainy and dry seasons (from January 2007 to January 2008).

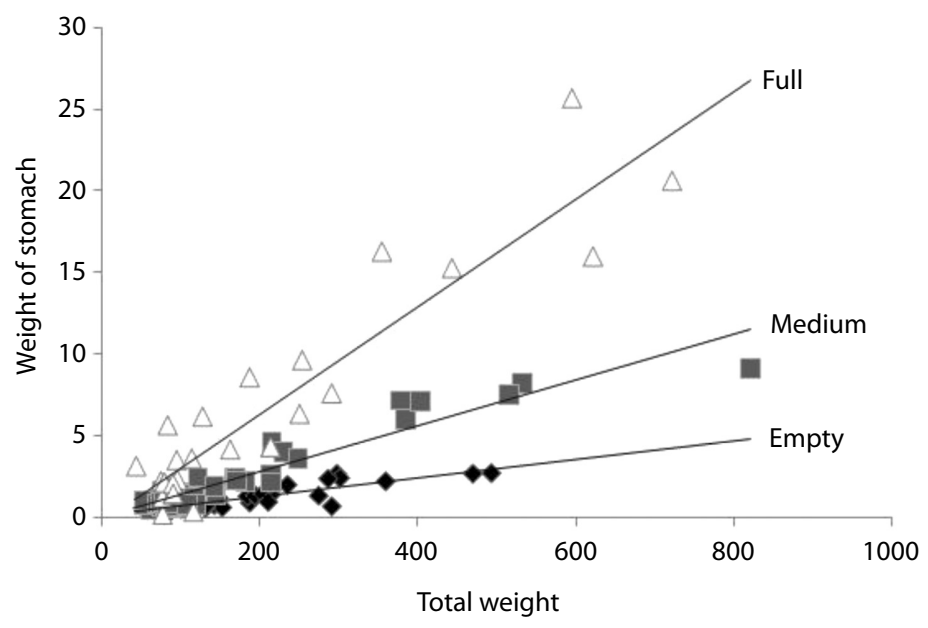

Fig. 9. Weights of stomachs in full, medium full and empty conditions in blue peacock (C. piquiti ) from Cachoeira Dourada reservoir (Paranaíba River basin, Brazil) plotted against its total weight.

Muñoz et al. (2006) observed length distribution frequencies in other species of Cichla, in which the males grew longer than the females; however, in these cases, pressures arising from fishing and unstable habitats may have contributed to these differences (Winemiller 2001).
An important biological characteristic in populations of introduced fish is the change in the median length at first gonadal maturity from the value in the native habitat. At present, it is impossible to verify whether this length changed after the introduction of $C$. piquiti to 
central Brazil, owing to the lack of research data on this variable in the native populations of the Tocantins-Araguaia river basin. Up to 2006, blue peacock fish were grouped in 15 species and $C$. piquiti was not defined as a separate species, being treated as a synonym of several of them. For this reason, changes in biological characteristics that may have occurred when this species was introduced into new habitats cannot be checked until studies in the original river systems have been completed. Therefore, the size at first gonadal maturity $(22.5 \mathrm{~cm})$ of $C$. piquiti populations in the Cachoeira Dourada reservoir, which was the same for males and females and fell in the $4^{\text {th }}$ size class, is compared here with those of other Cichla species elsewhere. Zaret (1980) reported that in Lake Gatun, Panama, female and male C. ocellaris (Bloch \& Schneider 1801) start reproducing at standard lengths of 32.2 and $33.2 \mathrm{~cm}$, respectively. In Venezuela, Winemiller et al. (1997), Jepsen et al. (1999) \& Winemiller (2001) found that the standard length at first maturity varied with the species: $32.5 \mathrm{~cm}$ for $C$. temensis (Humboldt 1821), $27.0 \mathrm{~cm}$ for $C$. orinocensis (Humboldt 1821) and $24.6 \mathrm{~cm}$ for $C$. intermedia (Machado-Allison 1971). However, in southeast Brazil, Gomiero \& Braga (2004) found this length to be shorter: $20.0 \mathrm{~cm}$ for $C$. ocellaris and $21.5 \mathrm{~cm}$ for C. monoculus (Spix \& Agassiz 1831). Similarly, in the Lobo reservoir (state of São Paulo), Souza et al. (2008) described the total length at first maturity of $\mathrm{C}$. kelberi (Kullander \& Ferreira 2006) as $20.7 \mathrm{~cm}$ for females and $21.5 \mathrm{~cm}$ for males. Such variations in the length at first maturity may be caused by a number of factors, such as species differences, therefore several criteria used in the estimation, adaptation of species to new lakes (Souza et al. 2008) or even seasonal variations. Gomiero et al. (2009) suggest that the overpopulation and full development of blue peacock fish at reduced sizes occur because of the absence of natural predators in the ecosystem and the great abundance of food.

The reproductive activity of species of Cichla takes place during the dry season, after which spawning occurs when the rains come and the water level begins to rise (LoweMcConnell 1969, Jepsen et al. 1999, Winemiller 2001). Some mature gonads were found in specimens of $C$. piquiti from the Cachoeira Dourada reservoir throughout the year of study, the numbers peaking in the dry period, suggesting a long reproductive phase. The constant presence of mature gonads confirms the continuous reproduction indicated by the observation that juveniles were collected in all seasons of the year. Long reproductive periods have been seen in natural habitats, in lakes and in reservoirs where Cichla spp. have been introduced (Gomiero et al. 2009). In the case of $C$. kelberi (Souza et al. 2008) and $C$. monoculus (Chellapa et al.2003), reproductive peaks occurred during the rainy periods, when the water was warmer. The tendency to synchronize reproduction can be explained by the higher levels of food available to the recentlyhatched fry (Gomiero et al. 2009). Resende et al. (2008), who studied the invasion of $C$. piquiti in the Central-west Brazilian swamplands (Pantanal) of the Mato Grosso plateau, noted that a significant number of mature and post-spawning (empty) gonads in an adult population of invaders is a clear sign that the population has become well established in the new habitat.

The stomach contents revealed that $C$. piquiti has a predominantly piscivorous eating habit, but most stomachs were empty in the rainy season. Seasonal availability of prey and variation of water transparency may influence when the reproductive period occurs. During the dry season, these fish consume more food and build up reserves for the reproductive phase, investing all their energy in gonad development. According to Zaret (1980) and Jepsen et al. (1997, 1999), Cichla spp. do not normally feed during spawning and while caring for the young. This agrees with the observation that in the Paraguay River $80 \%$ of blue peacock fish caught in the breeding season had empty stomachs (Muñoz et al. 2006).

Versatility of feeding habit is probably the chief reason for the notable success of cichlids in colonizing new habitats (Novaes 
et al. 2004). Fish of their own genus, characid fish and benthic animals are the food items often found in blue peacock fish stomachs (Jepsen et al. 1997, Williams et al. 1998, Lowe-MacConnell 1987). There are in fact 5 carnivorous fish species in Cachoeira Dourada reservoir: Acestrorhynchus lacustris (Lutken 1975), Hoplias malabaricus, H. lacerdae, Pinirampus pirinampu and Serrasalmus maculatus (Kner 1858). The introduced cichlid examined in our study attained a frequency similar to these species and apparently does not form part of the diet of $P$. pirinampu. On the other hand, the high incidence of young blue peacock fish in the food items identified in the stomachs of adult blue peacock fish demonstrates that the species practices a degree of population control. Nikolsky (1963) suggested that many acts of cannibalism to regulate abundance and reduce competition for food are a result of overpopulation. In this study, the diversity of food items in cichlid stomachs increased in the second size class and then, from the fourth class on, the variety of food narrowed as the fish reached sexual maturity. In Serra da Mesa reservoir (Brazil), adult C. monoculus fed mainly on fish, whereas their young swallowed microcrustaceans and insects, as well as fish. Moreover, insects and plants sometimes found in the stomachs of some adults could be the remains of food in the stomachs of their prey or material swallowed by chance while they caught the prey (Novaes et al. 2004).

Piscivorous invaders probably cause the composition of the invaded community to change more radically than invading omnivores or detritivores (Moyle \& Light 1996). The presence of these highly adapted and rapidly multiplying predators provokes serious damage to the ichthyofauna by predation, competition and a cascade of effects down the whole food chain (Arcifa \& Meschiatti 1993, Santos et al. 1994). In the Brazilian Rosana reservoir, biodiversity declined progressively and, several species of fish were lost completely in a few years following the introduction of $C$. kelberi (Pelicice \& Agostinho 2008). In Panama, when C. ocellaris spread to the region around the
Chagres River, a large number of fish species disappeared and changes also occurred in the zooplankton, aquatic insects and piscivorous birds, leading to a simplification of the food chain (Zaret \& Paine 1973). Godinho et al. (1994) made a comparative study of the ichthyofauna in the various lakes in the Rio Doce valley (Brazil) and observed that in the lakes colonized by $C$. ocellaris small species of fish had disappeared. Santos et al. (1994) reported that Cichla spp. and Plagioscion squamosissimus (Heckel 1840), both of which were exotic in the Rio Grande basin (S.E. Brazil), dominated the community of fish in the Furnas and Marimbondo reservoirs of that system.

Changes in the patterns of birth, death and migration in populations of native species result from ecological interactions between native and invading species, directly either through, by predation and competition or indirectly by alteration of habitats (Sakai et al. 2001). According to Lodge (2001), the Nile perch remained at low population levels for many years after being introduced into Lake Victoria (in the 1950s). However, it recently increased in abundance, provoking significant changes in the behavior of native prey fish, leading to the extinction of about 200 of the 400 cichlids in the lake.

When the blue peacock fish is introduced into a system with the simplified set of ecological relations, as those found in reservoirs, a population explosion can be expected, owing to the species characteristics observed in this study, namely the diminished size at first maturity, continuous reproduction and highly successful breeding, the absence of predators or natural competitors and the consumption of carnivores. Nevertheless, in Cachoeira Dourada reservoir, species are apparently not being excluded and the density of $C$. piquiti is near that of other piscivores in the reservoir. Given that this cichlid has become well established in an ecosystem where the ecological relations have been greatly reduced as a result of anthropogenic activity, modifications in the structure of the entire local community would be expected. However, it seems that, for the 
moment, there is a balance in which the blue peacock fish is sharing functions with the native carnivore species, and that this situation may be sustained by the diversity of foraging fish present in the reservoir.

\section{ACKNOWLEDGMENTS}

We are grateful for the financial support from ENDESA and Capes.

\section{RESUMEN}

El pez tucunaré (Cichla piquiti), nativo del sistema de la cuenca del rio Tocantins-Araguaia, fue introducido en la cuenca del río Paranaíba, parte del sistema del río Paraná. En este ecosistema trófico de planicie aluvial, las relaciones entre comunidades de peces están definidas por diferentes factores que pueden ser modificados debido a la represa del río, y da como resultado grandes cambios en la interacción biológica en éstos hábitats. La represa de Cachoeira Dourada forma parte de una serie de represas en el río Paranaíba en el Brasil central, donde el tucunaré se ha establecido. Una investigación sobre su espectro alimentario, combinado con información sobre sus características reproductivas y estructura poblacional, ha permitido evaluar el estado actual de esta especie y la obtención de datos útiles para el manejo de otras especies nativas en el mismo hábitat. Este estudio muestra que el tucunaré no tiene depredador o competidor natural en esta represa y se reproduce continuamente con tasas reproductivas muy altas, por lo tanto presenta una longitud media en su primera madurez (L50) más pequeña que otras especies de Cichla. El éxito de su establecimiento en estos hábitats fuertemente afectados por la actividad humana puede causar cambios en toda la estructura de la comunidad local. Sin embargo, en las represas parece que las funciones de estas especies son compartidas con las de los peces depredadores nativos, una situación que puede ser sustentada por la presencia de una larga variedad de peces forrajeros.

\section{REFERENCES}

Agostinho, A. \& A. Zalewski. 1995. The dependence of fish community struture and dynamics on floodplain and riparian ecotone zone in Paraná River, Brazil. Hydrobiologia 303: 141-148.

Agostinho, A.A., H.F. Júlio Jr \& M.J. Petrere. 1994. Itaipu Reservoir (Brazil): impacts of the impoundment on the fish fauna and fisheries, p. 161-184. In I.G. Cowx (ed.). Rehabilitation of freshwater fisheries. Fishing New Books, Oxford, England.
Agostinho, A.A., L.C. Gomes, D.R. Fernandez \& H.I. Suzuki. 2002. Efficiency of fish ladders for neotropical Ichthyofauna. River Res. Appl. 18: 299-306.

Agostinho, A.A., F.M. Pelicice \& L.C. Gomes. 2008. Dams and the fish fauna of the Neotropical region: impacts and management related to diversity and fisheries. Braz. J. Biol. 68: 1119-1132.

Arcifa, M.S. \& A.J. Meschiatti. 1993. Distribution and feeding ecology of fishes in a Brazilian reservoir: Lake Monte Alegre. Interciência 18: 302-313.

Barlow, G.W. 1974. Contrasts in social behavior between Central American cichlid fishes and coral-reef surgeon fishes. Am. Zool. 14: 9-34.

Benedito-Cecilio, E. \& C.A.R.M. Araujo-Lima. 2002. Variation in the carbon isotope composition of Semaprochilodus insignis, a detritivorous fish associated with oligotrophic and eutrophic Amazonian rivers. J. Fish. Biol. 60: 1603-1607.

Blossey, B. \& R. Notzold. 1995. Evolution of increased competitive ability in invasive non-indigenous plants: a hypothesis. J. Ecol. 83: 887-889.

Cabral, J.B.P., V.A. Bcegato, I. Scopel \& R.M. Lopes. 2005. Uso de técnicas de geoprocessamento para mapear o potencial natural de erosão da chuva na Bacia Hidrográfica do Reservatório de Cachoeira Dourada - GO/MG. RA`E GA. 10: 107-116.

Chellappa, S., M.R. Câmara, N.T. Chellappa, M.C.M. Beveridge \& F.A. Huntingford. 2003. Reproductive ecology of a neotropical cichlid fish, Cichla monoculus (Osteichthyes: Cichlidae). Braz. J. Biol. 63: $17-26$.

Godinho, A.L., M.T. Fonseca \& L.M. Araújo. 1994. The ecology of predator fish introductions: the case of Rio Doce Valley lakes, p. 77-85. In R.M.P. Coelho, A. Giani \& E. Sperling. Ecology and human impacts on lakes and reservoirs in Minas Gerais with special reference to future and management strategies. Segrac, Belo Horizonte, Brazil.

Gomiero, L.M. \& F.M.S. Braga. 2004. Feeding of introduced species of Cichla (Perciformes, Cichlidae) in Volta Grande reservoir, river Grande (MG/SP). Braz. J. Bio. 64: 787-795.

Gomiero, L.M. \& F.M.S. Braga. 2005. The condition factor of fishes from two river basins in São Paulo state, Southeast of Brazil. Acta Sci. Biol. Sci. 27: 73-78.

Gomiero, L.M., G.A. Villares Jr. \& F. Naous. 2009. Reproduction of Cichla kelberi (Kullander and Ferreira, 
2006) introduced into an artificial lake in southeastern Brazil. Braz. J. Biol. 69: 175-183.

Grime, J.P. 1979. Plant strategies and vegetation processes. Wiley, Chichester, United Kingdom.

Gurgel, H.C.B. 2004. Estrutura populacional e época de reprodução de Astyanax fasciatus (Cuvier) (Characidae, Tetragonopterinae) do Rio Céara Mirim, Poço Branco, Rio Grande do Norte, Brasil. R. B. Zool. 21: 131-135.

Hyslop, E.J. 1980. Stomach content analysis - a review of methods and their application. J. Fish Biol. 17: 411-429.

Jepsen, D.B., K.O. Winemiller \& D.C. Taphorn. 1997. Temporal patterns of resource partitioning among Cichla species in a Venezuelan blackwater river. J. Fish Biol. 51: 1085-1108.

Jepsen, D.B., K.O. Winemiller, D.C. Taphorn \& O.D. Rodriguez. 1999. Age structure and growth of peacock cichlids from rivers and reservoirs of Venezuela. J. Fish Biol. 55: 433-450.

Kaufman, L. 1992. Catastrophic change in species-rich freshwater ecosystems: the lessons of Lake Victoria. BioSciense 42: 846-858.

Kawakami, E. \& G. Vazzoler. 1980. Método gráfico e estimativa de índice alimentar aplicado no estudo de alimentação de peixes. Bol. Inst. Oceanogr. 29: 205-207.

Kratzer, C.R. \& P.L.A. Brezonik. 1981. Carlson-type trophic state index for nitrogen in Florida lakes. Water Resour. Bull. 17: 713-715.

Kullander, s.O. \& E.J.G. Ferreira. 2006. A review of the South American cichlid genus Cichla, with descriptions of nine new species (Teleostei: Cichlidae). Ichthyol. Expl. Freshwaters 17: 289-398.

Le Cren, E.D. 1951. The length-weight relationship and seasonal cycle in gonad weight and condition in the perch (Perca fluviatilis). J. Anim. Ecol. 20: 201-219.

Lodge, D. 2001. Responses of lake biodiversity to global changes, p. 277-312. In F.S. Chapin III, O.E. Sala \& E. Huber-Sannwald (eds.). Future scenarios of global biodiversity. Springer, New York, USA.

Lowe-McConnell, R.H. 1969. The cichlid fishes of Guyana, South America, with notes on their ecology and breeding behavior. Zool. J. Linn. Soc. 48: 255-302.

Lowe-McConnell, R.H. 1987. Ecological studies in tropical fish communities. Cambridge, London, England.
Moyle, P.B., H.W. Li \& B.A. Barton. 1986. The Frankenstein effect: impact of introduced fishes on native fishes in North America, p. 415-426. In R.H. Stroud (ed.). Fish culture in fisheries management. American Fisheries Society, Bethesda, Maryland, USA.

Moyle, P.B. \& J.J. Cech Jr. 1996. Fishes: an introduction to ichthyology. Prentice Hall, Englewood Cliffs, USA.

Moyle, P.B. \& T. Light. 1996. Biological invasions of fresh water: empirical rules and assembly theory. Biol. Conserv. 78: 149-161.

Muñoz, H., P.A. Van Damme \& F. Duponchelle. 2006. Breeding behaviour and distribution of the tucunaré Cichla aff. monoculus in a clear water river of the Bolivian Amazon. J. Fish. Biol. 69: 1018-1030.

Nikolsky, G.V. 1963. The ecology of fishes. Academic, London, England.

Novaes, J.L.C., E.P. Caramaschi \& K.O. Winemiller. 2004. Feeding of Cichla monoculus Spix, 1829 (Teleostei: Cichlidae) during and after reservoir formation in the Tocantins River. Acta Limnol. Bras. 16: 41-49.

Pelicice, F.M. \& A.A. Agostinho. 2008. Fish fauna destruction after the introduction of a non-native predator (Cichla kelberi) in a Neotropical reservoir. Biol. Invasions 11: 1789-1801.

Resende, E.K., D.K.S. Marques \& L.K.S.G. Ferreira. 2008. A successful case of biological invasion: the fish Cichla piquiti, an Amazonian species introduced into the Pantanal. Brazil. Braz. J. Biol. 68: 799-805.

Rocha, O., E.L.G. Espíndola, N. Fenerich-Verani, J.R. Verani \& A.C. Rietzler. 2005. Espécies invasoras em águas doces estudos de caso e propostas de manejo. EDUFSCar, São Carlos, Brazil.

Sakai, A.K., F.W. Allendorf, J.S. Holt, D.M. Lodge, J. Molofsky, K.A. With, S. Baughman, R.J. Cabin, J.E. Cohen, N.C. Ellstrand, D.E. McCauley, P. O'Neil, I.M. Parker, J.N. Thompson \& S.G. Weller. 2001. The population biology of invasive species. Rev. Ecol. Syst. 32: 305-32.

Santos, E.P. 1978. Dinâmica de populações aplicada à pesca e piscicultura. Hucitec/Edusp, São Paulo, Brazil.

Santos, G.B., P.M. Maia-Barbosa, A. Giani \& E.M. Von Sperling. 1994. Fish and zooplankton community structure in reservoirs of Southeastern Brazil: effects of the introduction of exotic predatory fish, p. 115132. In R.M. Pinto, A. Giani \& E. Von Sperling (eds.). Ecology and human impact on lakes and reservoirs in Minas Gerais with special reference to future development and management strategies. Segrac, Belo Horizonte, Brazil. 
Simberloff, D. 2003. Confronting introduced species: a form of xenophobia? Biol. Invasions 5: 179-192.

Souza, J.E., E.N. Fragoso-Mouro, N. Fenerich-Verani, O. Rocha \& J.R. Verani. 2008. Population structure and reproductive biology of Cichla kelberi (Perciformes, Cichlidae) in Lobo Reservoir, Brazil. Neotropical Ichthyology 6: 201-210.

Tilman, D. 1999 The ecological consequences of changes in biodiversity: a search for general principles. Ecology 80: 1455-1474.

Vazzoler, A.E.A.M. 1996. Biologia da reprodução de peixes teleósteos: teoria e prática. EDUEM, Maringá, Brazil.

Williams, J.D., K.O. Winemiller, D.C. Taphorn \& L. Balbas. 1998. Ecology and status of piscivores in Guri, and oligotrophic tropical reservoir. N. Am. J. Fish. Manag. 18: 274-285.

Winemiller, K.O., D.C. Taphorn \& A. Barbarino-Duque. 1997. Ecology of Cichla (Cichlidae) in two blackwater rivers of southern Venezuela. Copeia 4: 690-696.

Winemiller, K.O. 2001. Ecology of peacock cichlids (Cichla spp.) in Venezuela. J. Aquaric. Aquat. Scien. 9: 93-112.

Zaret, T.M. \& R.T. Paine. 1973. Species introductions in a tropical lake. Science 182: 449-455.

Zaret, T.M. 1980. Life history and growth relationships of Cichla ocellaris, a predatory South American cichlid. Biotropica 12: 144-157. 